\title{
Identifying critical factors for agility in innovation ecosystems: an exploratory study in the agriculture sector
}

\author{
Silvia Ronsom ${ }^{*}$ (D), Daniel Capaldo Amaral ${ }^{2}$ (D), José Eustáquio Ribeiro Vieira Filho ${ }^{3}$ (D) \\ ${ }^{1}$ Programa de Pós-graduação do Departamento de Engenharia de Produção, Escola de Engenharia de São Carlos - EESC, Universidade de São Paulo - USP, São \\ Carlos, SP, Brasil. E-mail: sronsom@gmail.com. \\ 2Programa de Pós-graduação do Departamento de Engenharia de Produção, Escola de Engenharia de São Carlos - EESC, Universidade de São Paulo - USP, São \\ Carlos, SP, Brasil.E-mail: amaral@sc.usp.br. \\ ${ }^{3}$ Diretoria de Estudos e Políticas Regionais, Urbanas e Ambientais - DIRUR, do Instituto de Pesquisa Econômica Aplicada - IPEA. Secretaria Executiva do \\ Ministério da Agricultura, Pecuária e Abastecimento - MAPA. Programas de Pós-Graduação em Agronegócios da Universidade de Brasília (PROPAGA/UNB) \\ e de Economia Aplicada da Universidade Federal de Viçosa (PPGEA/UFV), Brasília, DF, Brasil. E-mail: jose.vieira@ipea.gov.br.
}

\begin{abstract}
Organizational agility is the ability of organizations to adapt and respond to changes, it has been cited to explain the internal dynamics and competition in innovation ecosystems. Would it be possible to identify differences in agility as a measure in such environments? The present article investigates the subject, beginning with a systematic literature review that identified critical factors for agility in innovation ecosystems. Next, an exploratory field study was carried out to identify whether such factors could be observed empirically. An innovation ecosystem in the agriculture sector was chosen - the Brazilian Agricultural Research Corporation - Embrapa. The study allowed identifying agility factors in three sublevels of analysis, the last two being observed at Embrapa: Programs and Portfolios, Organizations and Ecosystems. Finally, future research that focuses on better understanding the phenomenon in innovation ecosystems is recommended.
\end{abstract}

Keywords: agility, innovation ecosystems, critical factors, Embrapa, exploratory study.

\section{Introduction}

The concept of "innovation ecosystems" is increasingly important for understanding the new reality, based on innovation and connectivity. This dynamic has required organizations to adapt (Sull, 2009; Organisation for Economic Co-operation and Development - OECD, 2015), an aspect directly related to agility.

Agility can be understood as an adaptive ability (Gunasekaran, 1999; Conforto et al., 2016), with authors suggesting it could explain performance differences between ecosystems that compete with each other (Rubens et al., 2011; Iansiti \& Euchner, 2018). Such ability is, therefore, essential to explain the dynamics of competition between these ecosystems.

Many authors use the term agility to explain the phenomena related to the innovation ecosystem. Despite this relevance, ecosystem agility has not been specifically defined in the field of innovation ecosystem theory.

In the search carried out for this study, between April and June 2020, from a total of 51 articles, 46 agility definitions were found, 32 definitions from areas such as agile manufacturing (e.g., Mihardjo et al., 2019; Liu \& Yang, 2020), and project management (e.g., Gonzalez, 2014). Another 14 definitions were freely proposed by the authors, without sources or structured scientific basis (e.g., Krstic et al., 2018; Vanharanta et al., 2018).

In the same search, no studies that measure or observe the agility construct in ecosystems were found, as well as studies describing agility factors that analyzed it from a practical and empirical point of view. Therefore, to assess the importance of whether or not there is an agility effect, it is essential to describe these elements.

The objective of this research was to identify a set of factors related to agility in innovation ecosystems that can be used to start describing the phenomenon. The research was carried out in two stages. In the first, through a systematic bibliographic review, factors potentially related to the agility of the ecosystem were identified, organizing them into levels of analysis. A field research was carried out in the second stage to identify examples of these factors in an innovation ecosystem in the agricultural sector in Brazil. Therefore, we carried out the analysis from the point of view of an organization that serves as a hub for more than one ecosystem in the agricultural sector, the Brazilian Agricultural Research Corporation (Embrapa).

Received: November, 1, 2021. Accepted: December, 22, 2021

*Corresponding author: Silvia Ronsom. E-mail: sronsom@gmail.com 
The study presents a synthesis of the concept of innovation ecosystems and identifies potential agility factors, cited in studies on innovation ecosystems. Then, the evidence of these factors was verified in an exploratory and qualitative way, based on the perspective of Embrapa's leaders. The analysis indicates the theory's potential in understanding the challenges and transformations of its innovation ecosystem.

\section{Methodology}

The research began by preparing a research project and the study of primary sources on Ecosystems, such as that by Iansiti \& Euchner (2018), Gomes et al. (2018), Walrave et al. (2018), and Carayannis \& Campbell (2009). In the area of Agile Management, the definition of agility by Conforto et al. (2016) was the starting point, complemented by the work of Beck et al. (2001), Boehm \& Turner (2004), Amaral et al. (2011).

In parallel, a documental analysis was carried out with the objective of mapping, in broad lines, the discussions about research management, agricultural technology and innovation, and Embrapa's institutional reports that mention the theme agility. The content is presented in section 3.2.

The procedure adopted for the SLR (Systematic Literature Review) was based on Conforto et al. (2011). The main conceptual elements related to agility and, respectively, research organizations, innovation ecosystems, and innovation management, were identified in the scientific databases (Web of Science and Scopus). A selection of articles that included such terms in the titles and abstracts was performed. Readings and content analysis were performed for 51 articles, as shown in Table 1.

Table 1. Number of articles read for the SLR.

\begin{tabular}{lccc}
\hline \multicolumn{1}{c}{ Research } & WoS & Scopus & Total \\
\hline Agility "E" research organizations & 9 & 14 & 23 \\
Agility "E" Innovation ecosystems & 8 & 13 & 21 \\
Agility "E" Innovation Management & 3 & 4 & 7 \\
Total & 20 & 31 & 51 \\
\hline
\end{tabular}

Source: Prepared by the authors.

Deductive analysis and open coding techniques were used for content analysis. Open coding means that notes and titles of content categories are written in the text during the reading, the material is read as many times as necessary, all aspects of the content are described and the categories are freely generated (Elo \& Kyngäs, 2007). The review is presented in section 4.

In the field, identifying examples of agility factors at Embrapa took place according to the following steps.

- Preparing an interview script generated from the review results.

- Interview planning, taking into consideration the selection of experts ( 5 respondents). All were long-standing professionals with decades of dedication to the institution and holding board positions or former directors of Embrapa and decentralized units.

- Conducting the interviews. The interviews were experimental and exploratory (Gil, 1999). The objective was to verify, whether the factors identified in the literature would be found in Embrapa and its units, according to the expert's descriptions. The objective did not include identifying correlations between variables.

Finally, for data analysis, the information obtained in the interviews was consolidated, analyzed for its relevance to the topic, and presented in section 5. Results and Discussion of the exploratory study.

\section{Theoretical background}

\subsection{The evolution of agility: from manufacturing to ecosystems}

The term "agility" has been discussed around the world to gain competitiveness and improve the innovation capabilities of the environments for which they are destined (Sull, 2009). The primary references of this research focus (Goldman, Nagel and Preiss, 1995; Gunasekaran, 1999; Sharifi and Zhang, 2001) on specific areas of knowledge, such as agility in manufacturing organizations, agility in the product development process, and project management.

In manufacturing, the term "agile manufacturing" has been characterized as an ability to change the configuration of a system in response to unforeseen changes and unexpected market conditions (Goldman et al., 1995; Gunasekaran, 1999; Sharifi \& Zhang, 2001). 
In the product development process, agility has been adopted to improve management methods (Cooper \& Edgett, 2009; Conforto \& Amaral, 2016).

In project management agility is quite widespread, with works such as Beck et al. (2001); Cohn (2005). Conforto et al. (2016, p.8) define the term agility as being "an ability of the project team to rapidly change project plans in response to stakeholder needs, market or technology demands, to achieve better project or product performance in an innovative and dynamic environment."

In terms of measuring agility, Conforto et al. (2016) list two factors: 1) the parties' flexibility to change project plans; and 2) active involvement of the client, that is, the participation of these entities in the technological solution, the object of project development.

The adoption of agile methodologies and the concept of agility have also been discussed for large scales (Dingsøyr \& Moe, 2014; Paasivaara et al., 2013). Rigby et al. (2016) stated that expanding and mature agile methods would be used on a large scale in companies from different areas.

Strategic agility is also cited in the public sector, considered a fundamental factor in adapting to the challenges and opportunities of the socio-economic scenario (Organização para a Cooperação e Desenvolvimento Econômico, 2015). Among these broader studies of agility, some articles analyze innovation ecosystems.

\subsection{The role of agility in innovation ecosystems}

An innovation ecosystem, according to Carayannis \& Campbell (2009, p. 202), is a set of "people, culture and technology interacting to catalyze creativity, trigger inventions and accelerate innovation across scientific and technological disciplines, from the public and private sectors, both in top-down, policy-oriented strategies and bottomup interventions, based on entrepreneurship." This definition is used because it highlights public-private collaboration, a reality that is closely related to collaboration and technological innovation, which is the focus of this work.

Among numerous configurations, some ecosystems involve Research and Development (R\&D) activities, as suggested by Nambisan \& Baron (2013), and those that study a set of entities, such as research centers, that collaborate to predict and develop innovations, as pointed out by Zahra \& Nambisan (2012)

More recently, the importance of the agility aspect in these environments has been identified. For example, it is observed that agility is a means by which the fundamental "species" (keystones) can be used to adapt their performance and keep the ecosystem functioning. This allows the evolution of other actors and their commitment to the ecosystem (Iansiti \& Euchner, 2018).

Examples such as Tesla Motors and Bosch indicate this phenomenon. Tesla adopts agile practices by constantly testing ideas between partners to quickly solve their problems (Stringham et al., 2015). Bosch has a program to implement rapid methods for validating business models on a large scale, which contributes to the success of its innovation portfolio (Osterwalder et al., 2020).

Innovation ecosystems with the presence of actors or the main "hub" can also be observed in the agricultural area. Douthwaite \& Hoffecker (2017) describe the transformation from a systemic approach to a more open dynamic agricultural approach, where researchers and rural producers are partners in the solutions, indicating the presence of ecosystems and agility factors.

In Brazil, Embrapa is a successful case of a research organization that, based on science and technology-based agriculture, promoted innovation (Alves, 2010). The interesting aspect of the case is that it acts as one of the main knowledge and innovation hubs for agricultural research in Brazil. The Institution has several units, developing new technologies in thematic areas and/or biomes, and in constant contact with rural producers and companies in the sector, as evidenced in Romani et al. (2020).

As in other ecosystems, the term agility is increasingly used in Brazilian agribusiness and also at Embrapa. Vieira Filho et al. (2020) point to the development of agility as a potential path for institutional changes in agribusiness. Embrapa's innovation policy (Embrapa, 2018) cites agility as a development strategy but does not indicate which are the main factors to achieve this goal. There is evidence that research development needs to be clarified.

\section{Analysis factors for innovation ecosystems}

The analysis of the set of selected articles allowed identifying agility patterns, classified into 3 sublevels:

- Sublevel 1. Programs and portfolios. Identified references for managing programs and project portfolios in ecosystem environments.

- Sublevel 2. Organizations. Studies related to research organizations, research centers, and occasional innovation startups that interact in ecosystems. 
- Sublevel 3. Ecosystem. It involves broad and complex innovation environments, including, for example, groups of self-organized agents and research centers of companies with decentralized and/or global operations.

\subsection{Sublevel of programs and portfolios}

In the agricultural sector, Douthwaite \& Hoffecker (2017) presents activities for research programs to adapt to changes in the agricultural sector: 1) Consensus for comprehensive challenges; 2) Regular review of visions, research questions, plans, and progress made; 3) Action and autonomous decision of groups and platforms for problem-solving at different scales.

Sweetman \& Conboy (2018) presents proposals for managing agile project portfolios based on Complex Adaptive Systems that focus on the following properties: self-organization; common purpose; autonomy; adaptability; variety of requirements; exchange of resources.

In the industry-academic environment, Sandberg et al. (2011) presented 10 principles of action: focus on ensuring results; ensure management engagement; adopt research negotiations; organize meetings; regularly communicate progress and results; meet needs and goals; be agile, admit frequent deliveries; finance small projects; innovation stemming from needs; apprenticeships.

Vidmar (2019) and Vidmar et al. (2020) report the adoption of project management approaches with agility, involving research partners, key users, and other stakeholders (funders, regulators, etc.) in different sets of projects.

Conforto \& Amaral (2016) present empirical data on the use and effect of a (hybrid) framework for project management in technology-based companies.

The results are summarized in Table 2 .

Table 2. Agility Factors for Programs and Portfolios.

\begin{tabular}{cc}
\hline Agility Factors & References \\
\hline Align an essential agility vision or message & Sandberg et al. (2011); Douthwaite \& Hoffecker (2017) \\
$\begin{array}{c}\text { Apply methods and techniques to adapt to change } \\
\text { (Examples: gates; participatory research; user stories, vision } \\
\text { monitoring) }\end{array}$ & Cooper (2014); Douthwaite \& Hoffecker (2017); \\
$\begin{array}{c}\text { Frameetman \& Conboy (2018) } \\
\text { (software or others) }\end{array}$ & \\
& Gonzalez (2014); Conforto \& Amaral (2016); Cooper (2014).
\end{tabular}

Source: Prepared by the authors based on the set of articles identified in the literature.

It was possible to observe the presence of these factors in other levels too, but with some specificities presented as follows.

\subsection{Sublevel of organizations}

Shin et al. (2015), state that in organizations, strategic agility positively influences internal alignment or "strategic consensus". Chikhale \& Mansouri (2015) point out the importance of building consensus and trust, by identifying stakeholder groups and developing action plans.

Liu \& Yang (2020) argue that organizations that seek agility should operate less by rules and more based on principles, favoring entrepreneurial behavior.

Teoh \& Cai (2015) state that the anticipation and response process as agility components are associated with anticipation capabilities, knowledge transformation, synchronization to solve problems and accommodate changes, interaction with customers, and adaptability.

Framework proposals and the use of collaborative platforms were identified in several studies. Weiblen \& Chesbrough (2015) stood out for presenting a typology of corporate engagement models with startups and their main objectives: Startup program (Outside-In and platform); Corporate Incubation; Corporate business.

The results are summarized in Table 3.

Table 3. Agility factors in the Organizations sublevel.

\begin{tabular}{cc}
\hline Factors & References \\
\hline Align an agility vision (or essential message) & Cross (2015); Shin et al. (2015); Chikhale \& Mansouri (2015); \\
Liu \& Yang (2020)
\end{tabular}




\begin{tabular}{|c|c|}
\hline Factors & References \\
\hline $\begin{array}{l}\text { Apply methods and techniques to adapt to change } \\
\text { (Examples: winning over relevant stakeholders; } \\
\text { balance between innovation and risk management) }\end{array}$ & Teoh \& Cai (2015); Vanharanta et al. (2018); Liu \& Yang (2020) \\
\hline Continuous learning or by design & Pérez-Bustamante (1999); Teoh \& Cai, 2015 \\
\hline Entrepreneurial behavior & Katzy \& Crowston (2008); Liu \& Yang (2020) \\
\hline Develop an agile mindset and capabilities & $\begin{array}{c}\text { Pérez-Bustamante (1999); Mihardjo et al. (2019); } \\
\text { Kuivalainen et al. (2020) }\end{array}$ \\
\hline Develop collaboration and learning & Pérez-Bustamante (1999); Shin et al. (2015); Vidmar (2019) \\
\hline Develop leadership & Meyer \& Marion (2010); Krstic et al. (2018); Liu \& Yang (2020) \\
\hline $\begin{array}{l}\text { Frameworks or collaborative management platforms } \\
\text { (software or others) }\end{array}$ & $\begin{array}{l}\text { Calof \& Smith (2010); Meyer \& Marion (2010); Cross (2015); } \\
\text { Shin et al. (2015); Weiblen \& Chesbrough (2015); Chikhale \& } \\
\text { Mansouri (2015); Adegbile et al. (2017); Houngbe et al. (2019); } \\
\text { Liu \& Yang (2020) }\end{array}$ \\
\hline Gradual or staged implementation & Teoh \& Cai (2015); Cross (2015); Fritzsch et al. (2019); \\
\hline Exchange of resources on networks & Meyer \& Marion (2010); Liu \& Yang (2020) \\
\hline
\end{tabular}

Source: Prepared by the authors based on the set of articles identified in the literature.

The factor "Align an agility vision (or essential message)" is found in Organizational level, encompassing the members of entire organization, not only in the portfolio domain, like previously presented. The same occurs in adoption of frameworks or collaborative management platforms. This reinforces the premise that idea of agility is changing and expanding, and to align such vision are crucial in the entire organizational, embedded in ecosystems environments.

As exemplified in Table 3, it was also possible to observe new methods and techniques, different from those considered in Program and Portfolio level (Table 2).

\subsection{Sublevel of ecosystem}

This section presents management actions and decisions at the inter-organizational, ecosystem level, and the critical factors related to the challenges of agility development.

Vidmar (2019) and Vidmar et al. (2020) identified the practice of using a core message for innovation and cross-sector collaboration in the development of products, services, and their support infrastructure for the Space Industry in Scotland. This practice is close to another one observed by Klerkx et al. (2010), which is the participation of specialized innovation brokers to help formulate and reformulate the vision. This sharing helps the continuous adaptation of the actors' network, which can impact agility.

After the vision, there is the coordination of platforms, as observed by Argyropoulou et al. (2019), who defended the importance of an agile entity that manages a variety of scientific fields and coordinates various financing mechanisms. Chikhale \& Mansouri (2015) present similar ideas but focus on the case of Apple.

Weinberg (2019) described a historical perspective on the changing role of government support in business ecosystems in Israel. The process includes the introduction of public/private support agencies designed to be more flexible and agile to meet the changing needs of businesses, clusters, and ecosystems.

Mergel's (2016) proposal for a research agenda in agile innovation management at the national level was based on three principles: a) open innovation for software development, in which partners should also apply agile methodologies; b) need for an agile leadership approach; c) alternative contracting approaches and iterations that allow identifying small flaws for quick correction, starting from the specification phase.

The author presented a proposal for an agile approach including a base layer, formed by policies; an umbrella management layer, based on agile, process management, and leadership methodologies.

Among the aspects mentioned that fit more in the sub-level of organizations, some of them are related to ecosystems. Two mechanisms stood out, the agile BPAs (Blanket Purchase Agreements) and RFP (Requests for Proposal).

Kuivalainen et al. (2020) consider agile practices to deal with a learning paradox in R\&D units in a global chain of companies. It was observed that none of these authors properly defined what this agility in decisions about ecosystems is and how to implement it.

The results are summarized in Table 4.

Table 4. Agility factors in the Ecosystem sub-level. 


\begin{tabular}{cc}
\hline Operational factors & References \\
\hline Align an agility vision (or essential message) & Klerkx et al. (2010); Chikhale \& Mansouri (2015); Mergel (2016); \\
Vidmar (2019); Vidmar et al. (2020) \\
Platform coordination \\
Flexible and agile structures \\
Entrepreneurial behavior \\
Klerkx et al. (2010); Argyropoulou et al. (2019); Weinberg (2019) \\
Weinberg (2019); Vidmar (2019); Vidmar et al. (2020) \\
Develop collaboration and learning \\
$\begin{array}{c}\text { Krameworks or collaborative platforms (software or } \\
\text { others) }\end{array}$ \\
$\begin{array}{c}\text { Klerkx et al. (2010); Katzy \& Crowston (2008) } \\
\text { Kuivalainen et al. (2020); Vidmar et al. (2020) }\end{array}$ \\
$\begin{array}{c}\text { Apply methods and techniques (Examples: } \\
\text { BPAs; participatory critical path analysis; reflective } \\
\text { process monitoring) }\end{array}$ \\
Exchange of resources on networks
\end{tabular}

Source: Prepared by the authors based on the set of articles identified in the literature.

As mentioned, again it was found some factors observed in previous levels, but applicable in the Ecosystem level. In case of alignment of agility vision, the entire ecosystem encompasses new complexities, different from the Organizational level, with a variety of actors involved. It could be an indicator of the likely influence of constructs from the ecosystem area, such as the alignment of actors discussed by Adner (2017), and not yet discussed jointly with the agility construct.

This is probably an opportunity for discussion to agility in innovation ecosystems that requires new research efforts. The same occurs to other factors such as frameworks and application of new methods and techniques. As presented in the literature review, and synthetized in Table 4, a case of application of a method or technique nominated of BPAs (Blanket Purchase Agreements), can be making a difference in actor's relationships of an ecosystem, in order to contribute with more agility to alignment of actors. But more conceptual discussions and empirical observations would be needed.

\section{Exploratory study in agroindustrial ecosystems}

The agility factors identified in Tables 1,2, and 3 were transformed into an interview script, applied to EMBRAPA managers at the board level, as presented in the method section.

In this exploratory study, we identify evidences just for Organizational and Ecosystem level, as discussed in the subsections.

\subsection{Sublevel of organizations}

\subsubsection{Application of methods and techniques to adapt to change}

Citations of agile management practices and methods were identified by managers of some units, such as periodic review of plans; weekly alignment with the Unit's guidelines; light visual planning model; and periodic and constant communication and monitoring with the team.

Although timid, the existence of this type of action indicates the search for incorporating agile practices, which configures a path of experimentation and use of hybrid management approaches (e.g. Conforto et al., 2015). Therefore, there is an opportunity to study hybridism and its potential application in the Embrapa system, as can be seen in the example of the agenda presented by Mergel et al. (2018).

\subsubsection{Developing leadership}

In one of the Units interviewed, the process of improving and developing careers was observed. It was possible to verify the discourse aligned with aspects that promote agile management, for example:

- ongoing guidance in relationships; and focus on purpose - the Unit as a solution provider and mediator of interests;

- valuing the trajectory, however, focusing on the Unit as a bearer of the future;

- management and communication of alerts, such as: "if the team does not understand the adaptations, they risk doing dispersed work";

- learning for prioritization and internal competitiveness;

- concern with the profile, for example, the balance between experience and young members with leadership potential who can help build lighter management; 
- apply the idea of self-management;

- applying the concept of vision for team motivation (Benassi, Amaral and Ferreira, 2016) as a means to maintain constant unit orientation.

According to Bäcklander (2019), there is a concern regarding the formal and informal balance provided by leaders to leverage the dynamics of Complex Adaptive Systems and produce learning, creativity, and adaptation in organizations. The identified initiatives demonstrated the potential for developing this factor, with a focus on agility.

\subsubsection{Developing an agile mindset and capabilities}

Directive management focused on fulfilling a negotiable agenda among internal members was observed, which considers developing: the institutionalization of a new integration mentality for innovation, (not the individualized vision as it was in the past); analytical profile - aimed at changing a position; internal innovation agents, people dedicated to understanding the structure of the Unit and multiplying it.

\subsubsection{Frameworks or collaborative management platforms}

In Embrapa's Technology Prospecting and Assessment Sector, cases of adaptation in management frameworks and instruments to the reality of one of the Units were identified.

The adaptations comprise aspects of strategic intelligence to analyze the need for new skills, with improvements in the analysis of opportunities; apply the TRL (Technology Readiness Level) to guide the project portfolio; typification of projects; process reconfigurations; improvements in asset qualification; review of indicators; maturity assessment models in R,D\&I management processes; the anticipation of resources, and decision autonomy for specific types of innovation projects.

Actions related to technological prospecting in the Organization would be carried out more dynamically. They are in line with work by Vishnevskiy et al. (2015), which pointed out the lack of integrated and constantly updated technological roadmaps to enhance innovation network strategies, and Carlos et al. (2018), which developed a model for the continuous updating of roadmaps, combining concepts of agility and competitive intelligence.

Another example that can help with new management frameworks and tools was documented in Reynolds et al. (2019) and Ronsom \& Amaral (2019) regarding the case of Embrapii. In the Embrapii system, Science and Technology Institutions (STIs) have the autonomy to manage project resources, one of the few practical cases that can be related to the dimension of the flexibility of financial resources, pointed out in the OECD study (2015) for strategic agility.

\subsection{Sublevel of ecosystem}

\subsubsection{Flexible and agile structures}

Adaptations in the management structure of the Units were identified through the structuring of a Technological Innovation Center (NIT) in one of the Units. This is an embryo concerning that established at Embrapa, enabling greater flexibility for managing resources in specific cases of that Unit.

This structure can be analyzed from the perspective of living laboratories (Leminen, 2015; Vidmar, 2019; Fecher et al., 2020), which would be proposals for new and dynamic structures that could be expanded or remodeled more naturally at Embrapa. As well as other adaptation modes of management structures that reduce barriers between sectors, according to Bäcklander (2019).

\subsubsection{Platform coordination}

The frequency of interaction between those involved in managing a range of scientific fields in the network was identified, with the practice of constant dialogues on sector policies (with policymakers). The proximity between these actors, through the coordination of platforms, is a movement that has been discussed in cases such as Apple (Chikhale \& Mansouri, 2015) and European platforms (Argyropoulou et al., 2019) which can contribute to agility at Embrapa.

Regarding the involvement of agents, the practice of ranking and aligning initiatives was identified, which seek synergies with the strategy of the Center and the Unit, to design future actions. The involvement of agents in the network, as mentioned above, was reported in Klerkx et al. (2010), but it is also a conceptual element for measuring agility, according to Conforto et al. (2016).

\subsubsection{Influence of the public/private sector}

Although not highlighted in the Literature Review, governance in a public environment was identified as an issue that should be better analyzed. The respondents recognize the challenge of being flexible and, consequently, agile in dealing with aspects related to regulated environments. 
It is possible to develop a collective commitment as a way to integrate behaviors and increase flexibility without the institution losing control. Within the scope of cutting-edge research in agile management, solutions are beginning to emerge.

Fitzgerald et al. (2013) present discussions on the notion of continuous compliance and active traceability. Silva (2019) presented a synthesis of the literature on the practices used to adapt agile models aimed at regulated environments. And, as cited, Mergel et al. (2018) presented a research agenda on agility in US government organizations. The studies could contribute to the discussion about reducing bureaucratic levels and improving governance at Embrapa.

\section{Conclusion}

The article contributes to the identification of factors that can determine the agility of an innovation ecosystem according to the literature found for this research field. The factors were classified into three sub-levels of analysis: Programs and Portfolios, Organizations, and Ecosystems.

It was possible to observe that some factors occur in different levels, with some specificities that confirm the expansion of agility theory to wide environments. It signalizes the probably relationship of the agility construct with new variables in ecosystem environment, as the alignment of actors. The literature review results can be evaluated by researchers interested in expanding the knowledge on the subject.

The set of factors that emerged from the literature guided an exploratory study to identify the potential presence of these agility indicators in an innovation ecosystem in Brazilian agribusiness. Embrapa, which has cited the term agility in its policies, had not yet been analyzed according to agility factors that emerged from the literature.

The interviews carried out with managers of EMBRAPA units allowed us to identify agility factors at the Organization level: application of methods and techniques; leadership development and agile mindset; collaborative frameworks. At the Ecosystem level, aspects related to platform coordination, new management structures that are being made more flexible, as well as aspects related to the influence of the public and private sector on the performance of the Ecosystem were identified, an additional factor to the set of factors studied in the literature. As for the level of Programs and portfolios, there is a need for further analysis of Embrapa's environment. In this first exploratory study, no evidences were found for this level.

This article highlights the need to expand efforts to obtain a framework that is capable of rigorously defining and helping to characterize agility in innovation ecosystems.

\section{Funding source}

IPEA/MAPA.

\section{Acknowledgements}

This research was supported with resources from "Rede de Pesquisa Integrada IPEA-MAPA". The research team thanks the Ministry of Agriculture, Livestock and Supply (Mapa), the Institute for Applied Economic Research (Ipea), the Brazilian Agricultural Research Corporation (Embrapa) and the University of São Paulo (USP) for facilitating the structuring and development of that study.

\section{References}

Adegbile, A., Sarpong, D., \& Meissner, D. (2017). Strategic foresight for innovation management: a review and research agenda. International Journal of Innovation and Technology Management, 14(4), 1750019.

Adner, R. (2017). Ecosystem as structure: an actionable construct for strategy. Journal of Management, 43(1), 39-58. http://dx.doi.org/10.1177/0149206316678451.

Alves, E. (2010). Embrapa - um caso bem-sucedido de inovação institucional. Política Agricola, XIX(spe), 65-73.

Amaral, D., Conforto, E., Benassi, J.-L., \& Araújo, C. (2011). Gerenciamento ágil de projetos: aplicação em produtos inovadores. São Paulo: Saraiva

Argyropoulou, M., Soderquist, K. E., \& Ioannou, G. (2019). Getting out of the European Paradox trap: making European research agile and challenge driven. European Management Journal, 37, 1-5.

Bäcklander, G. (2019). Doing complexity leadership theory: how agile coaches at Spotify practise enabling leadership. Creativity and Innovation Management, 28, 42-60.

Beck, K., Beck, K., Beedle, M., van Bennekum, A., Cockburn, A., Cunningham, W., Fowler, M., Grenning, J., Highsmith, J., Hunt, A., Jeffries, R., Kern, J., Marick, B., Martin, R. C., Mellor, S., Schwaber, K., Sutherland, J., \& Thomas, D. (2001). Manifesto for agile software development. Retrieved in 2020, February 10, from https://agilemanifesto.org/iso/ptbr/manifesto.html. 
Benassi, J. L., Amaral, D. C., \& Ferreira, L. D. (2016). Towards a conceptual framework for product vision. International Journal of Operations \& Production Management, 36(2), 200-219.

Boehm, B., \& Turner, R. (2004). Balancing agility and discipline: a guide for the perplexed. Boston: Addison-Wesley.

Calof, J., \& Smith, J. (2010). The integrative domain of foresight and competitive intelligence and its impact on R\&D management. $R \&$ D Management, 40(1), 31-39.

Carayannis, E. G., \& Campbell, D. F. J. (2009). 'Mode 3' and 'quadruple helix': toward a 21 st century fractal innovation ecosystem. International Journal of Technology Management, 46(3-4), 201-234.

Carlos, R., Amaral, D. C., \& Caetano, M. (2018). Framework for continuous agile technology roadmap updating. Innovation \& Management Review, 15(3), 321-336.

Chikhale, M., \& Mansouri, M. (2015). An agile and collaborative framework for effective governance to enhance management in large-scale enterprise business systems: the case of Apple Inc. Global Journal of Flexible Systems Management., 16, $283-293$.

Cohn, M. (2005). Agile estimating and planning. New York: Prentice Hall PTR.

Conforto, E. C., Silva, F. B., Amaral, D., \& Rebentisch, E. (2015). Modelos híbridos unindo complexidade, agilidade e inovação. Revista Mundo PM, 70(2), 10-57.

Conforto, E., \& Amaral, D. C. (2016). Agile project management and stage-gate model: a hybrid framework for technology-based companies. Journal of Engineering and Technology Management, 40, 1-14.

Conforto, E., Amaral, D. C., \& Silva, S. L. (2011). Roteiro para revisão bibliográfica sistemática: aplicação no desenvolvimento de produtos e gerenciamento de projetos. In Laboratório de Otimização de Produtos e Processo (LOPP) (Org.), $8^{\circ}$ Congresso Brasileiro de Inovação e Gestão do Desenvolvimento de Produto (CBGDP). UFRGS

Conforto, E., Amaral, D. C., Silva, S., Felippo, A., \& Kamikawachi, D. (2016). The agility construct on project management theory. International Journal of Project Management, 34, 660-674.

Cooper, R. G. (2014). What's next? After stage-gate. Research Technology Management, 57, $20-31$.

Cooper, R., \& Edgett, S. (2009). Product innovation and technology strategy. Ancaster: Product and Development Institute Inc.

Cross, S. E. (2015). A model to guide organizational adaptation. In Institute of Electrical and Electronics Engineers (IEEE) (Org.), 2013 International Conference on Engineering Technology and Innovation ICE 2013 and IEEE International Technology Management Conference. IEEE.

Dingsøyr, T., \& Moe, N. (2014). Towards principles of large-scale agile development. In: T. Dingsøyr, N. Moe, R. Tonelli, S. Counsell, C. Gencel \& K. Petersen (Eds.), Agile Methods. Large-Scale Development, Refactoring, Testing, and Estimation (vol. 199, pp. 1-8). Springer.

Douthwaite, B., \& Hoffecker, E. (2017). Towards a complexity-aware theory of change for participatory research programs working within agricultural innovation systems. Agricultural Systems, 155, 88-102.

Elo, S., \& Kyngäs, H. (2007). The qualitative content analysis process. London: Sage

Embrapa. (2018). Política de Inovação da Embrapa. Retrieved in 2020, February 10, from https://www.embrapa.br/politica-deinovacao Acessado em 16/04/2019.

Fecher, F., Winding, J., Hutter, K., \& Füller, J. (2020). Innovation labs from a participants' perspective. Journal of Business Research, 110, 567-576.

Fitzgerald, B., Stol, K. J., O’Sullivan, R., \& O’Brien, D. (2013). Scaling agile methods to regulated environments: an industry case study, In Institute of Electrical and Electronics Engineers (IEEE) (Org.), Proceedings of International Conference on Software Engineering (ICSE) (pp. 863-872). IEEE.

Fritzsch, J., Bogner, J., Wagner, S., \& Zimmermann, A. (2019). Microservices migration in industry: intentions, strategies, and challenges. In Institute of Electrical and Electronics Engineers (IEEE) (Org.), Proceedings - 2019 IEEE International Conference on Software Maintenance and Evolution. IEEE.

Gil, A. (1999). Como elaborar projetos de pesquisa. Atlas: São Paulo.

Goldman, S. L., Nagel, R. N., \& Preiss, K. (1995). Agile competitors and virtual organizations: strategies for enriching the customer. New York: Van Nostrand Reinhold.

Gomes, L. A. V., Facin, A. L., Salerno, M. S., \& Ikenami, R. K. (2018). Unpacking the innovation ecosystem construct: evolution, gaps and trends. Technological Forecasting and Social Change, 136, 30-48.

Gonzalez, W. (2014). Applying agile project management to predevelopment. International Journal of Innovation and Technology Management, 11(4), 1450020.

Gunasekaran, A. (1999). Agile manufacturing: a framework for research and development. International Journal of Production Economics, 62, 87-105

Houngbe, M., Barthe-Delanoe, A. M., \& Negny, S. (2019). A systemic approach for agile biorefineries. In G. Stephanopoulos (Ed.), 29th European Symposium on Computer Aided Process Engineering, Pt B. Pergamon.

Iansiti, M., \& Euchner, J. (2018). Competing in Ecosystems. Research Technology Management, 61(2), 10-16.

Katzy, B. R., \& Crowston, K. (2008). Competency rallying for technical innovation - the case of the Virtuelle Fabrik. Technovation, 28, 679-692.

Klerkx, L., Arts, N., \& Leeuwis, C. (2010). Adaptive management in agricultural innovation systems: the interactions between innovation networks and their environment. Agricultural Systems, 103, 390-400.

Krstic, M., Skorup, A., \& Lapcevic, G. (2018). Trends in agile innovation management. International Review, 3, 58-70. 
Kuivalainen, J, Kunttu, I, \& Kohtamaki, M. (2020). Agile product development practices for coping with a learning paradox in R\&D offshore units. Technology Innovation Management Review, 10(3), 69-77.

Leminen, S. (2015). Living labs as open innovation networks - Networks, roles and innovation outcomes. Helsinki: Aalto University.

Liu, H.-M., \& Yang, H.-F. (2020). Network resource meets organizational agility: creating an idiosyncratic competitive advantage for SMEs. Management Decision, 58(1), 58-75.

Mergel, I. (2016). Agile innovation management in government: a research agenda. Government Information Quarterly, 33(3), 516-523

Mergel, I., Gong, Y., \& Bertot, J. (2018). Agile government: systematic literature review and future research. Government Information Quarterly, 35, 291-298.

Meyer, M. H., \& Marion, T. J. (2010). Innovating for effectiveness: lessons from design firms. Research Technology Management, 53(5), 21-28

Mihardjo, L., Sasmoko, S., Alamsyah, F., \& Elidjen, D. (2019). Boosting the firm transformation in industry 5.0: experience-agility innovation model. International Journal of Recent Technology and Engineering (IJRTE), 8(2), 737-742.

Nambisan, S., \& Baron, R. A. (2013). Entrepreneurship in innovation ecosystems: Entrepreneurs' self-regulatory processes and their implications for new venture success. Entrepreneurship Theory and Practice, 37(5), 1071-1097.

Organização para a Cooperação e Desenvolvimento Econômico - OCDE. (2015). Achieving public sector agility at times offiscal consolidation. OECD Public Governance Reviews. Paris: OECD Publishing.

Osterwalder, A., Pigneur, Y., Smith, A., \& Etiemble, F. (2020). The invincible company. Hoboken: John Wiley \& Sons, Inc.

Paasivaara, M., Lassenius, C., Heikkila, V., Dikert, K., \& Engblom, C. (2013). Integrating global sites into the lean and agile transformation at ericsson. In Institute of Electrical and Electronics Engineers (IEEE) (Org.) IEEE 8th International Conference on on Global Software Engineering (pp. 134-143). IEEE.

Pérez-Bustamante, G. (1999). Knowledge management in agile innovative organisations. Journal of Knowledge Management, 3, 6-17.

Reynolds, E. B., Schneider, B. R., \& Zylberberg, E. (2019). Innovation in Brazil, advancing development in the 21 st Century. London: Routledge.

Rigby, D., Sutherland, J., \& Takeuchi, H. (2016). Embracing agile. Harvard Business Review, 2016.

Romani, L., Bambini, M. D., Bariani, J. M., Drucker, D. P., Minitti, A. F., Farah, A., Kuromoto, V. M., Telles, G. A., Araújo, R., Dias, C. N., Assunção, B. S., Souza, S. S., Luchiari Júnior, A., \& Meira, C. A. (2020). Ecossistema de inovação em agricultura: evolução e contribuições da Embrapa. In S. M. F. S. Massruhá, M. A. A. Leite, S. R. M., Oliveira, C. A. A., Meira, A. Luchiari Junior, \& E. L. Bolfe (Eds.), Agricultura digital: pesquisa, desenvolvimento e inovação nas cadeias produtivas. Brasília: Embrapa. Retrieved in 2020, April 20, from https://ainfo.cnptia.embrapa.br/digital/bitstream/item/218132/1/LV-Agricultura-digital-2020-cap12.pdf.

Ronsom, S., \& Amaral, D. (2019). Avaliando o potencial de aplicação do conceito de agilidade na gestão de tecnologia em ICTs: o caso EMBRAPII. In . In Laboratório de Otimização de Produtos e Processo (LOPP) (Org.), $12^{\circ}$ Congresso Brasileiro de Inovação e Gestão do Desenvolvimento de Produto (CBGDP). UFRGS.

Rubens, N., Still, K., Huhtamäki, J., \& Russell, M. G. (2011). A network analysis of investment firms as resource routers in Chinese innovation ecosystem. Journal of Software, 6(9), 1737-1745.

Sandberg, A., Pareto, L., \& Arts, T. (2011). Agile collaborative research: action principles for industry-academia collaboration. IEEE Software, 28(4), 74-83.

Sharifi, H., \& Zhang, Z. (2001). Agile manufacturing in practice. Application of a methodology. International Journal of Operations \& Production Management, 21, 772-794

Shin, H., Lee, J. N., Kim, D., \& Rhim, H. (2015). Strategic agility of Korean small and medium enterprises and its influence on operational and firm performance. International Journal of Production Economics, 168, 181-196.

Silva H. L. (2019). Avaliação das práticas de qualidade assegurada em modelos híbridos de gestão de projetos aplicados em ambientes regulados [Dissertação de Mestrado]. Escola de Engenharia de São Carlos, Universidade de São Paulo, São Carlos.

Stringham, E. P., Miller, J. K., \& Clark, J. R. (2015). Overcoming barriers to entry in an established industry: Tesla Motors. California Management Review, 57(4), 85-103.

Sull, D. (2009). Competing through organizational agility. McKinsey Q. Retrieved in 2020, February 20, from http://www.mckinsey.com/insights/managing_in_incerainty/competing_through_organizational_agility.

Sweetman, R., \& Conboy, K. (2018). Portfolios of agile projects: a complex adaptive systems' agent perspective. Project Management Journal, 49(6), 18-38.

Teoh, S. Y., \& Cai, S. (2015). The process of strategic, agile, innovation development: a healthcare systems implementation case study. Journal of Global Information Management, 23(3), 1-22.

Vanharanta, H., Kantola, J., Markopoulos, E., Salo, M., Einolander, J., \& Hanhisalo, T. (2018). The degree of agility in a technology company's strategy, management, and leadership. Management and Production Engineering Review, 9(4), $129-137$.

Vidmar, M. (2019). Agile space living lab - the emergence of a new high-tech innovation paradigm. Space Policy, $49,101324$.

Vidmar, M., Rosiello, A., Vermeulen, N., Williams, R., \& Dines, J. (2020). New space and agile innovation: understanding transition to open innovation by examining innovation networks and moments. Acta Astronautica, 167, $122-134$.

Vieira Filho, J. E. R., Gasques, J. G., \& Ronsom, S. (2020). Inovação e expansão agropecuária brasileira. In J. E. R. Vieira Filho \& J. G. Gasques (Orgs.), Uma jornada pelos contrastes do Brasil: 100 anos de censo agropecuário. Brasília: Ipea.

Vishnevskiy, K., Karasev, O., \& Meissner, D. (2015). Integrated roadmaps and corporate foresight as tools of innovation management: the case of Russian companies. Technological Forecasting and Social Change, 90, 433-443. 
Walrave, B., Talmar, M., Podoynitsyna, K. S., Romme, A. G. L., \& Verbong Geert, P. J. (2018). A multi-level perspective on innovation ecosystems for path-breaking Innovation. Technological Forecasting and Social Change, 136, $103-113$.

Weiblen, T., \& Chesbrough, H. W. (2015). Engaging with startups to enhance corporate innovation. California Management Review, 57(2).

Weinberg, C. (2019). Entrepreneurial ecosystems in israel: the changing role of government support: a historical perspective. In In Institute of Electrical and Electronics Engineers (IEEE) (Org.), Portland International Conference on Management of Engineering and Technology (PICMET) (pp. 1-3). IEEE.

Zahra, S. A., \& Nambisan, S. (2012). Entrepreneurship and strategic thinking in business ecosystems. Business Horizons, 55(3), $219-229$. 